IZA DP No. 8613

Gender, Time-Use, and Fertility Recovery in Industrialized Countries

Javier García-Manglano

Natalia Nollenberger

Almudena Sevilla

November 2014 


\title{
Gender, Time-Use, and Fertility Recovery in Industrialized Countries
}

\author{
Javier García-Manglano \\ University of Oxford \\ Natalia Nollenberger \\ Queen Mary University of London \\ Almudena Sevilla \\ Queen Mary University of London \\ and IZA \\ Discussion Paper No. 8613 \\ November 2014 \\ IZA \\ P.O. Box 7240 \\ 53072 Bonn \\ Germany \\ Phone: +49-228-3894-0 \\ Fax: +49-228-3894-180 \\ E-mail: iza@iza.org
}

Any opinions expressed here are those of the author(s) and not those of IZA. Research published in this series may include views on policy, but the institute itself takes no institutional policy positions. The IZA research network is committed to the IZA Guiding Principles of Research Integrity.

The Institute for the Study of Labor (IZA) in Bonn is a local and virtual international research center and a place of communication between science, politics and business. IZA is an independent nonprofit organization supported by Deutsche Post Foundation. The center is associated with the University of Bonn and offers a stimulating research environment through its international network, workshops and conferences, data service, project support, research visits and doctoral program. IZA engages in (i) original and internationally competitive research in all fields of labor economics, (ii) development of policy concepts, and (iii) dissemination of research results and concepts to the interested public.

IZA Discussion Papers often represent preliminary work and are circulated to encourage discussion. Citation of such a paper should account for its provisional character. A revised version may be available directly from the author. 
IZA Discussion Paper No. 8613

November 2014

\section{ABSTRACT \\ Gender, Time-Use, and Fertility Recovery in Industrialized Countries}

This paper explores gendered patterns of time use as an explanatory factor behind fertility trends in the developed world. We review the theoretical foundations for this link, and assess the existing evidence suggesting that a more equal division of labor within the home leads to more children, both at the household (micro) and country (macro) levels. After decades of unprecedented fertility decline in the industrialized world, only a handful of countries in the West exhibit replacement fertility rates - around two children per woman. Paradoxically, birth rates are substantially lower in countries in which family units (and women within families) remain primarily responsible for familial care obligations, and where the role of the State in the provision of care services is marginal. Very low fertility poses challenges for economic growth and threatens the sustainability of pay-as-you-go welfare systems. It is thus important to understand why some developed countries managed to sustain near-replacement fertility rates or to recover from very low fertility, while others fell and still remain at lowest-low rates of about 1.3 children per woman. Looking at time-use and fertility trends for a few representative industrialized countries, we hint at the existence of a threshold ratio of gender equity in the distribution of domestic work that low fertility countries need to cross before being able to enter a phase of fertility recovery.

JEL Classification: J1, J11, J13

Keywords: childcare, housework, demographic transitions, fertility decline, low fertility, fertility trends, fertility recovery, gender equity, gender attitudes, gender division of housework, Multinational Time Use Study, time-use, time allocation, time diary data

Corresponding author:

Almudena Sevilla

Queen Mary University of London

School of Business \& Management

Mile End, Francis Bancroft Building, Room 4.12

London, E1 4NS

United Kingdom

E-mail: a.sevilla@qmul.ac.uk 


\section{Introduction}

During the 1980s, total fertility rates (TFR) in most advanced societies fell below 2.1 children per woman (Van De Kaa, 1987), a level known as replacement fertility -two children to replace their parents, and the remaining fraction to compensate for those who will remain childless or die before the end of their reproductive lives. Within the next decade, an important proportion of Southern and Eastern European countries -Belarus, Bosnia, Bulgaria, Czech Republic, Estonia, Greece, Hungary, Italy, Latvia, Romania, Russia, Slovenia, Spain, and Ukraine- reached rates below 1.3 children per woman (Billari and Kohler, 2004; Kohler et al., 2002), a level known as lowest-low fertility. Very low fertility poses challenges for academics and policy makers alike, as shrinking and aging populations jeopardize economic growth and threaten the sustainability of pay-as-you-go welfare systems. In the absence of offsetting changes in employment rates and productivity, structural adaptations may be required, with important implications for public pensions, health expenditures, and welfare (Weil, 1997).

Recently, scholars have documented a process of fertility recovery in several countries, particularly in the US and in Northern Europe (Goldstein et al., 2009; SánchezBarricarte and Fernández-Carro, 2007). This uptick in fertility might currently be spreading to other countries (Myrskylä et al., 2013; Sobotka, 2011) and possibly to more advanced regions within lowest-low fertility countries such as Italy (Caltabiano et al., 2009). Even if these trends might partially be attributed to methodological differences in the measurement of fertility (Bongaarts and Sobotka, 2012), the fact remains that recent fertility declines were not homogeneous across the West, stabilizing near replacement in some countries and falling to substantially lower levels in others. Paradoxically, fertility sank deepest in countries with a strong familialistic social policy (e.g. Southern Europe), where the role of the State in the 
provision of care services is marginal, and family units -and women within families- remain primarily responsible for familial care obligations (Esping-Andersen, 2009).

This article contributes to the existing fertility research by taking a multidisciplinary approach from Demography, Sociology, and Economics to identify an emerging area of research at the intersection between fertility and the gendered distribution of household labor. We use time diary data to present new cross-country evidence on the association between time use, gender and fertility. This approach can provide new insights as we seek to understand lowest-low fertility and the forces behind fertility recovery.

The paper is organized as follows. We begin by documenting the unprecedented fertility decline observed in industrialized countries after 1970, and highlight some of the sociological and economic explanations that have been advanced to explain these trends. Next, we review the theoretical link between fertility and gendered patterns of time use, and assess the existing evidence indicating that a more equal gender division of labor within the home leads to more children. We further investigate this hypothesis by comparing, for a sample of representative industrialized countries, trends in fertility and in the gender distribution of domestic work during the past fifty years. We close with the identification of avenues for future research.

\section{Fertility decline, ideational change, and opportunity cost}

The theory of the Second Demographic Transition (SDT) (Lesthaeghe and Surkyn, 1988; Lesthaeghe, 1995, 1983) attributes recent fertility declines to a process of ideational social change, by which fertility is no longer driven by concerns regarding basic human needs (food production in the home economy, old-age support and insurance, child survival, etc.), but geared instead towards the satisfaction of higher-order, post-materialistic needs (self- 
realization, expressive values, etc.) which do not require high fertility to be met. The SDT predicts structural below-replacement fertility in advanced populations (Lesthaeghe, 2007). Some authors even suggested that most countries would be trapped into very low fertility rates due to a combination of demographic -fewer women being born resulting in fewer future births- and sociological factors -declining fertility preferences derived from increased exposure to very low fertility-, among others (Testa et al., 2006).

The economic perspective relates fertility decline with increases in the cost of children, in particular the opportunity cost of time. Becker's original model of time allocation suggested that, as time became more valuable, the production -and consumption- of time intensive "commodities”, such as children, would be lower (Becker, 1965). Thus, increasing labor market opportunities for women would lead to higher female labor force participation and to fewer children (Becker, 1965; Willis, 1973). This increase in female wages over the last few decades is assumed to be unrelated to fertility declines; instead, female wage gains are attributed to factors such as technological change, which decreased the reliance on physical-intensive labor in favor of cognitive-intensive work, a transition which arguably suited better the labor market abilities of women (Galor and Weil, 1996). In addition, the diffusion of oral contraception contributed to marriage postponement and facilitated greater career investments from women (Goldin and Katz, 2002). Complementarily, the diffusion of home appliances played an important role in easing the demands of housework, increasing the responsiveness of female labor supply to changes in wages (Greenwood et al., 2005). Becker's prediction of a negative relationship between (female) wages and fertility was initially confirmed at the macro (Mincer, 1985) and micro levels -see Schultz (2001) for a review of this literature. As we will see below, this relationship would be challenged later using more recent data. 


\section{The heterogeneous fertility decline in advanced economies}

Fertility declines were not homogeneous across countries, resulting in varying birth rates among industrialized nations. As a result, today some countries exhibit TFRs near 2 children per woman, having managed never to drop far from replacement rates or to recover fertility. In contrast, fertility in some other countries remains substantially below replacement. This is illustrated in Figure 1, which presents fertility trends in select OECD economies from 1970 to 2011. We distinguish between two groups of countries: those where fertility did not decline as much or recovered -United States, Denmark, Finland and Norwayand those in which fertility decreased substantially over this period and remained at very low levels. The latter -Italy, Spain, Germany and Japan- present TFRs circa 1.3 children per woman since the early 1990s, a level known as lowest-low fertility.

Figure 1: Total Fertility Rates in selected industrialized countries

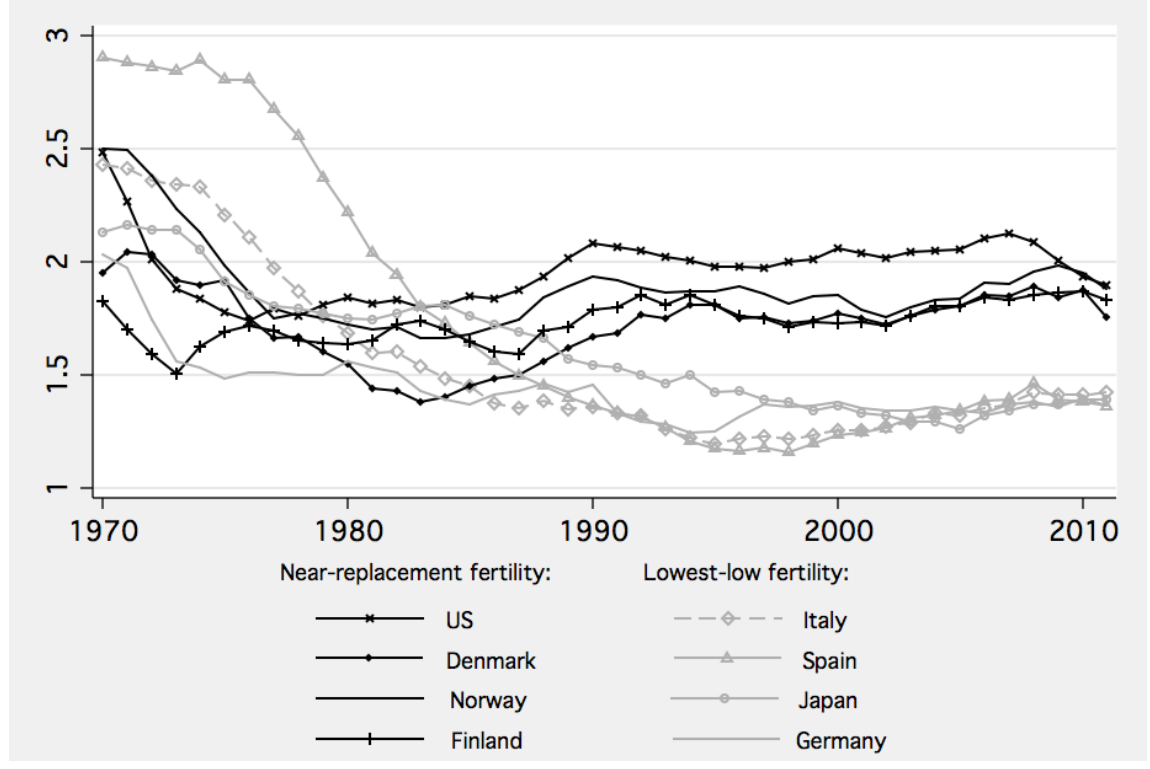

Source: OECD (2012).

Note: Total Fertility Rate (TFR) indicates the number of children that an average woman would have at the end of her reproductive life were she to follow the age-specific fertility patterns observed in a given population at a given time. 
The experience of fertility recovery in some countries challenged SDT's predictions of long-term low fertility and the hypothesis of a low fertility trap, by showing that countries can approach near-replacement fertility from below -i.e. after falling to lower levels. Indeed, SDT theory has been recently updated to account for rebounding fertility rates (Lesthaeghe, 2010). Similarly weakened is Becker's prediction of an inverse relationship between female wages and fertility, which no longer holds at the macro level. In the past, countries with lower female labor force participation rates had higher fertility levels, and vice-versa (Mincer, 1985), suggesting role incompatibility between the roles of mother and worker (Stycos and Weller, 1967). However, this relationship reversed in some nations after the mid1980s (Brewster and Rindfuss, 2000; Murphy, 2001) and, today, fertility is lowest in countries with lower female labor force participation rates (Ahn and Mira, 2002; De Laat and Sevilla-Sanz, 2011).

\section{Gendered patterns of time use and fertility recovery}

Two main developments are behind the fertility trends described above. First, male and female employment rates have been converging in OECD countries since the 1970s (Jaumotte, 2003). Second, men are increasingly involved in housework and childcare, especially in high-fertility countries (Aguiar and Hurst, 2007; Bianchi, 2000; Gimenez-Nadal and Sevilla, 2012; Kan et al., 2011). From these observations, a theory has emerged in parallel within Sociology, Demography and Economics, focusing on gender equity in the distribution of family responsibilities. This theory predicts that couples in which the man and the woman share equitably in home and market production will exhibit higher fertility outcomes than couples with a more gendered time use pattern. Gender equity in domestic work allows women to combine the rearing of children with market work, a preference shared by most women in advanced economies (Hakim, 2000). Higher fertility levels can 
thus be compatible with greater female labor force participation, as long as men take up a fair share of household responsibilities -see De Laat and Sevilla-Sanz (2011) for a formalization and application of this theory, and Bettio and Villa (1998) for a similar argument.

This theory could also help explain the process of fertility recovery observed in some countries -and the lack of recovery observed in others. Fertility recovery would thus depend on changes in the household division of labor, driven by gender norms. In particular, when women's wages are low -as they were before 1970 in most developed countries- women specialize in childcare and housework, having children comes with a low opportunity cost, and couples have more of them. In this context, social norms and economic considerations align as observed in the neoclassical home economics approach (Becker, 1991). EspingAndersen (2009) calls this the traditional "male breadwinner, female homemaker" equilibrium. However, as women’s wages rise -as they did after 1970- women’s bargaining power increases and efficiency considerations (i.e. staying at home becoming relatively more costly) lead to less household gender specialization. A "gender egalitarian" equilibrium is eventually reached, characterized by greater gender equity in the distribution of family duties, high female labor force participation, and fertility rates near replacement (De Laat and Sevilla-Sanz, 2006; Esping-Andersen et al., 2013; Feyrer et al., 2008; Goldscheider, 2012). However, there is an intermediate phase in which women's new labor market opportunities conflict with slowly evolving social norms -expectations that women are chiefly responsible for home production. In this middle stage, the high opportunity cost of time derived from increased female wages places additional stress on women, who face a "double burden" of market work and childcare (Hochschild and Machung, 1989; Milkie et al., 2009).

Using this theoretical approach, current cross-country differences in fertility rates could be explained, ceteris paribus, by the different gendered time-use patterns. Why have 
some countries completed the transition to a more gender equitable use of time faster than others? Borrowing from McDonald (2000a, 2000b), some authors argue that family policy is the main force behind these trends, since it promotes gender equity in settings -such as the tax code and paternity leave policy- that deal with people as members of families (EspingAndersen, 2009). Other scholars stress the importance of social norms, particularly those dealing with men's role in the family, and argue that the gender revolution will complete only when norms are more gender-neutral (Goldscheider et al., 2013). In any case, both approaches hinge on the growing body of evidence indicating that when men and women share more equitably in the worlds of work and home, couples reach higher levels of fertility (Esping-Andersen, 2009; Goldscheider, 2012).

As with aggregate fertility rates, similar patterns are observed at the household level: greater intra-household gender equity is associated with faster transitions to parenthood and to higher-order births, and with higher completed fertility. This general pattern is confirmed in a variety of countries, using several estimation techniques (Brodmann et al., 2007; Cooke, 2009, 2004; Goldscheider et al., 2013; Oláh, 2003). There is evidence for a U-shaped curve at the household level: couples with a traditional distribution of household responsibilities (male breadwinner, female homemaker), as well as those with more equitable gender roles, are more likely to transition to a second birth than couples with unequal but not specialized division of labor (Torr and Short, 2004).

\section{Evidence from time diary data}

Studies of fertility and the distribution of household responsibilities usually approximate time use patterns using gender attitudes and other proxies (such as father's use of parental leave). In contrast, time diary data provide a more accurate and direct picture of the gender division of domestic labor. A diary is completed by respondents on selected days, 
which are divided into intervals. For each of these intervals, respondents report the main activity they are engaged in, among other things (such as whether they were performing that activity alone or with others). In the remainder of this paper, we use time diary data from the past five decades to explore fertility trends in eight industrialized countries, and present some plausible hypotheses that could inform further research.

Table 1. Fertility and gender patterns of time use. 2000-2004.

\begin{tabular}{|c|c|c|c|c|}
\hline & \multirow{2}{*}{ TFR } & \multicolumn{3}{|c|}{ Ratio of men/women time devoted to: } \\
\hline & & Childcare & Housework & Paid work \\
\hline \multicolumn{5}{|c|}{ Near-replacement fertility } \\
\hline USA & 2.04 & 0.52 & 0.54 & 1.84 \\
\hline Norway & 1.80 & 0.45 & 0.67 & 1.81 \\
\hline Denmark & 1.76 & 0.51 & 0.73 & 1.54 \\
\hline Finland & 1.75 & 0.42 & 0.59 & 1.52 \\
\hline \multicolumn{5}{|c|}{ Lowest-low fertility } \\
\hline Germany & 1.35 & 0.43 & 0.48 & 2.48 \\
\hline Japan & 1.32 & 0.17 & 0.06 & 2.11 \\
\hline Italy & 1.28 & 0.41 & 0.22 & 2.67 \\
\hline Spain & 1.27 & 0.42 & 0.27 & 2.62 \\
\hline \multicolumn{5}{|c|}{$\begin{array}{l}\text { Sources: OECD (2012) and MTUS (2012). Because of lack of more recent } \\
\text { harmonized time-diary data, we report averages for the 2000-2004 period for all } \\
\text { outcomes. Time-use data for Japan come from the Survey on Time Use and } \\
\text { Leisure Activities (2001). } \\
\text { Note: MTUS is an ex-post harmonized cross-time, cross-national comparative } \\
\text { time-use database, constructed from national random-sampled time-diary studies. } \\
\text { The sample is restricted to individuals aged } 20 \text {-59 years old, living with a partner } \\
\text { in a household with at least one child under the age of } 18 \text {. }\end{array}$} \\
\hline
\end{tabular}

Table 1 shows average fertility rates and gender patterns of time use for the eight countries in Figure 1, for the early 2000s. Gendered patterns of time use are defined as the men-to-women ratio of time spent in a given activity. We distinguish between housework, childcare, and paid work. Countries are ranked by fertility rates, with those at the top (USA, Norway, Finland and Denmark) exhibiting a more gender egalitarian distribution of time. Men in these four near-replacement fertility countries devote over 50 percent of woman's time to housework and only between 50 and 85 percent more time than women to paid work. In contrast, in lowest-low fertility countries (Germany, Japan, Italy and Spain) men’s share in 
housework time is less than half of women's, with over twice as much time devoted to paid employment. There are only slight differences across groups in time devoted to childcare (these are uncommonly large in Japan) with women doing on average about twice as much as men; still, men's contribution to childcare is marginally higher in near-replacement countries.

Two other interesting facts emerge from these data. Firstly, there are greater crosscountry gender differences in housework and paid work time than in childcare time, suggesting that parents treat childcare -but not housework- as a form of investment (Guryan et al., 2008); as such, childcare may be less subject to change as a result of evolving social norms. Secondly, perfect gender equality (a value near 1 ) does not seem to be a requisite for near-replacement fertility levels; in fact, even the more egalitarian societies are far from full equality in these three important daily activities -childcare, housework, and paid work.

To further explore the fertility recovery hypothesis, Figure 2 presents time series of fertility, female labor force participation and domestic work (measured here as the sum of housework and childcare time) for selected countries within each fertility group. In countries with current fertility levels near replacement (US, Norway), fertility declined until the 1980s, but then a threshold ratio of men-to-women domestic work time (about 0.5) was crossed, and they began to recover fertility. In contrast, countries with lowest-low fertility levels (Italy, Spain) have yet to cross such threshold, and show no sign of sustained fertility recovery. Even more, these countries seem to be at different stages of a similar process: the gender pattern of domestic work observed in low fertility countries at the beginning of the 2000s is remarkably similar to that of near-replacement-fertility countries in the 1960s-1970s. However, new research (Sullivan et al. 2014 forthcoming) shows that, among lowest-low fertility countries, early signs of fertility recovery are associated with greater participation in 
domestic work among educated young men; to the extent that gender equitable attitudes diffuse, this could lead to future fertility gains among lowest-low fertility countries.

Figure 2: Trends in fertility, female labor force participation, and gender division of domestic work
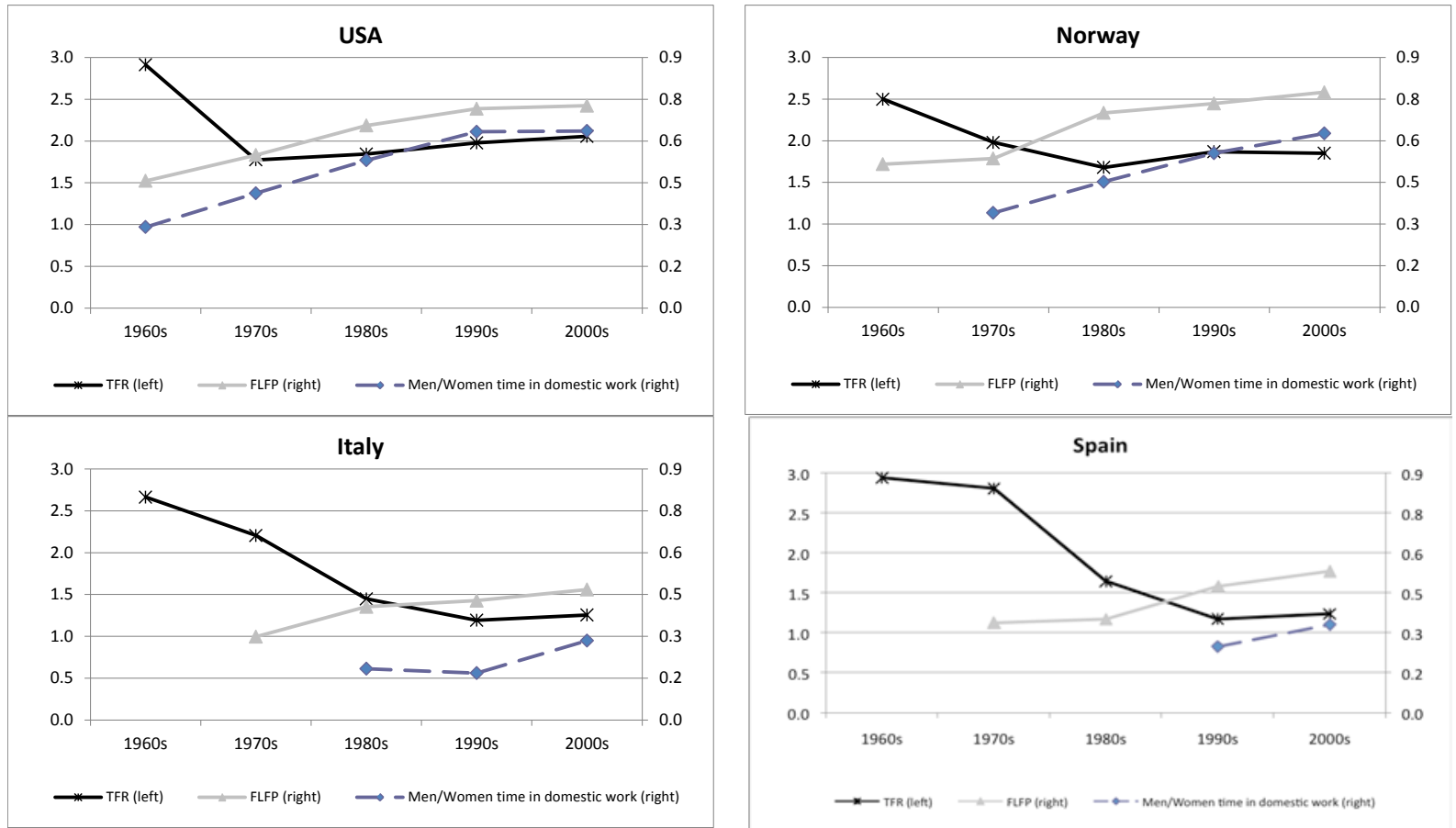

Sources: OECD (2012) and MTUS (2012).

Note: Figure displays Total Fertility Rate (TFR), Female Labor Force Participation (FLFP) and the womenmen ratio of time in domestic work (includes housework and childcare). Given that it is not possible to restrict the sample to households with children in the MTUS time series, we include all individuals aged 20-59 -unlike the numbers reported in Table 1. Given that parenthood exacerbates gender specialization in domestic work, we can consider the time estimates above a bit conservative.

\section{Conclusion and further research}

In the industrialized world, fertility declines varied in rates and timing across countries, resulting in two broadly-defined fertility regimes. In some countries, such as the US and Northern Europe, fertility never fell far below the replacement rate of 2.1 children per women, or bounced back and stabilized near that level. In Southern Europe, Germany and Japan, fertility declined to substantially lower levels without recovery. In this article, we reviewed an expanding area of research located at the intersection between fertility and the gender distribution of household labor, and presented cross-country evidence from time-diary 
data suggesting that increases in men's share of home production might partially explain fertility recovery in advanced economies.

Some questions remain which deserve further consideration. More could be said on the role of attitudes in mediating the relationship between gendered time use patterns and fertility. Golscheider et al. (2013) report that, in Sweden, what most depresses couples' fertility is the inconsistency between gender attitudes and behaviors: when "reality" in the distribution of housework (but not childcare) disagrees with women's “ideals” of fairness, second births (but not other-parity births) are significantly delayed. Similarly, Brodmann et al. (2007) find that the effect on fertility of a higher male contribution in housework is stronger for career oriented women.

This area of inquiry could also benefit from interdisciplinary dialogue. Complementary to arguments about gender equity and fairness -prevalent in Sociology and Demography- policy intervention could attend to reasons of economic efficiency. Prior economic research has identified peer effects and positive externalities in the spread of social norms and the diffusion of gender equitable behaviors (De Laat and Sevilla-Sanz, 2011), which in turn may affect childbearing decisions (Fernández and Fogli, 2006). Under positive externalities, couples who do not engage in egalitarian behavior can still free-ride on the benefits from higher aggregate fertility resulting from couples engaging in more equal division of labor. As a result, the number of egalitarian couples would be less than socially optimal. This suggests that, even if targeted to a limited number of individuals, intervention to reach a more equal sharing of housework and to increase fertility, would have rippling effects by increasing the fertility of other couples. Similarly, inefficiencies in the distribution of household chores and in the achievement of desired fertility could arise from imperfect information among partners, the possibility that they free-ride on each other's contributions 
due to the "public good" nature of children in the family (Lundberg and Pollak, 1993), given the difficulty in legally enforcing marital contracts designed to guarantee cooperation in the allocation of domestic time (De Laat and Sevilla-Sanz, 2011; Rasul, 2008).

Questions also remain on the relative importance of cultural and social norms vis-àvis institutional context and policy intervention. Distinguishing between norms and institutions is empirically hard, given the simultaneity of both processes; and findings so far are mixed. Some studies have used immigrants to isolate the effect of social norms (from the country of origin) from institutional factors (at destination), finding that characteristics of the country of origin play an important role in determining women's employment behavior (Fernández and Fogli, 2006; Fogli and Fernández, 2009). In contrast, Klüsener et al. (2013) exploited a natural experiment in a culturally and linguistically German region in Belgium (two countries with diverse fertility outcomes), to find that institutional and policy circumstances trump cultural norms when predicting fertility.

The descriptive associations presented in this paper also deserve further investigation. From our comparison across countries of recent trends in fertility and in the gender distribution of time in domestic activities, we advanced a tentative hypothesis: that there is a threshold level of domestic gender equity that needs to be crossed to trigger a process of fertility recovery in industrialized nations. Testing whether this threshold is similar across countries, or whether it is shaped by cultural or institutional factors, might constitute a fruitful avenue for future research. To that end, time diary data provide an invaluable resource. Important time-diary resources are already available such as the Multinational Time Use Study (MTUS, 2012) with more countries and waves being included and more data being harmonized every year, both from developed and developing countries. Such efforts should be continued and more widely used by researchers in the behavioral and social sciences. 
Cross references: Demographic Transition, Second; Families and Households, Behavioral Demography of; Family and Work; Family Theory: Economics of Childbearing; Fertility Change: Quantum and Tempo; Fertility: Institutional and Political Approaches; Fertility Transition: Cultural Explanations; Fertility Transition: Economic Explanations; Gender, Economics of; Social Networks and Fertility; Time Use and Gender; Time Use research methods; Work and Family.

\section{References}

Aguiar, M., Hurst, E., 2007. "Measuring Trends in Leisure: The Allocation of Time over Five Decades" The Quarterly Journal of Economics 122 (3): 969-1006.

Ahn, N., Mira, P., 2002. "A note on the changing relationship between fertility and female employment rates in developed countries" Journal of Population Economics 15(4): 667-682.

Becker, G.S., 1965. "A Theory of the Allocation of Time" The Economic Journal Vol. $75 \mathrm{~N}^{\circ}$ 229, pp 493-517.

Becker, G.S., 1991. A Treatise on the Family. Harvard University Press.

Bettio, F., Villa, P., 1998. "A Mediterranean Perspective on the Breakdown of the Relationship between Participation and Fertility" Cambridge Journal of Economics, 22: 137-71.

Bianchi, S.M., 2000. "Maternal Employment and Time with Children: Dramatic Change or Surprising Continuity?" Demography 37(4): 401-414.

Billari, F., Kohler, H.-P., 2004. "Patterns of low and lowest-low fertility in Europe" Population Studies 58(2): 161-176.

Bongaarts, J., Sobotka, T., 2012. "A Demographic Explanation for the Recent Rise in European Fertility" Population and Development Review 38(1): 83-120.

Brewster, K.L., Rindfuss, R.R., 2000. "Fertility and Women’s Employment in Industrialized Nations" Annual Review of Sociology 26: 271-296.

Brodmann, S., Esping-Andersen, G., Güell, M., 2007. "When Fertility is Bargained: Second Births in Denmark and Spain" European Sociological Review 23(5): 599-613.

Caltabiano, M., Castiglioni, M., Rosina, A., 2009. "Lowest-Low Fertility: Signs of a recovery in Italy?" Demographic Research 21: 681-718.

Cooke, L.P., 2004. "The gendered division of labor and family outcomes in Germany" Journal of Marriage and Family 66(5): 1246-1259.

Cooke, L.P., 2009. "Gender Equity and Fertility in Italy and Spain" Journal of Social Policy 38(1): 123-140. 
De Laat, J. de, Sevilla-Sanz, A., 2011. "The Fertility and Women’s Labor Force Participation puzzle in OECD Countries: The Role of Men's Home Production" Feminist Economics 17(2): 87-119.

De Laat, J., Sevilla-Sanz, A., 2006. "Working women, men's home time and lowest-low fertility". ISER Working Paper Series No. 2006-23.

Esping-Andersen, G., 2009. Incomplete Revolution: Adapting Welfare States to Women's New Roles. Polity.

Esping-Andersen, G., Boertien, D., Bonke, J., Gracia, P., 2013. "Couple Specialization in Multiple Equilibria" European Sociological Review 29(6): 1280-1294.

Fernández, R., Fogli, A., 2006. "Fertility: The Role of Culture and Family Experience" Journal of the European Economic Association 4(2-3): 552-561.

Feyrer, J., Sacerdote, B., Stern, A.D., 2008. "Will the Stork Return to Europe and Japan? Understanding Fertility within Developed Nations" The Journal of Economic Perspectives, 22(3): 3-22.

Fogli, A., Fernandez, R., 2009. "Culture: An Empirical Investigation of Beliefs, Work, and Fertility" American Economic Journal: Macroeconomics 1(1): 146-77.

Galor, O., Weil, D.N., 1996. "The Gender Gap, Fertility, and Growth" American Economic Review 86(3): 374-87.

Gimenez-Nadal, J.I., Sevilla, A., 2012. "Trends in time allocation: A cross-country analysis" European Economic Review 56(6): 1338-1359.

Goldin, C., Katz, L., 2002. "The Power of the Pill: Oral Contraceptives and Women's Career and Marriage Decisions" Journal of Political Economy 110 (4): 730-70.

Goldscheider, F., Bernhardt, E., Brandén, M., 2013. "Domestic gender equality and childbearing in Sweden" Demographic Research 29: 1097-1126.

Goldscheider, F.K., 2012. "The Gender Revolution and the Second Demographic Transition: Understanding Recent Family Trends in Industrialized Societies" in: 2012 European Population Conference “Gender, Policies and Population”. Stockholm.

Goldstein, J.R., Sobotka, T., Jasilioniene, A., 2009. "The End of 'Lowest-Low' Fertility?" Population and Development Review 35(4): 663-699.

Greenwood, J., Seshadri, A., Yorukoglu, M., 2005. "Engines of Liberation" Review of Economic Studies 72(1): 109-133.

Guryan, J., Hurst, E., Kearney, M., 2008. "Parental Education and Parental Time with Children" The Journal of Economic Perspectives 22(3): 23-46.

Hakim, C., 2000. Work-lifestyle choices in the 21st century: Preference theory. Oxford University Press, USA. 
Hochschild, A.R., Machung, A., 1989. The second shift: Working parents and the revolution at home. Viking New York.

Jaumotte, F., 2003. "Female Labour Force Participation: Past Trends and Main Determinants" in OECD Countries. OECD Economics Department Working Paper No. 376. OECD Publishing.

Kan, M.Y., Sullivan, O., Gershuny, J., 2011. "Gender Convergence in Domestic Work: Discerning the Effects of Interactional and Institutional Barriers from Large-scale Data" Sociology 45(2): 234-251.

Klüsener, S., Neels, K., Kreyenfeld, M., 2013. "Family Policies and the Western European Fertility Divide: Insights from a Natural Experiment in Belgium" Population and Development Review 39(4): 587-610.

Kohler, H.-P., Billari, F.C., Ortega, J.A., 2002. "The Emergence of Lowest-Low Fertility in Europe During the 1990s" Population and Development Review 28(4): 641-680.

Lesthaeghe, R., 1983. "A Century of Demographic and Cultural Change in Western Europe: An Exploration of Underlying Dimensions" Population and Development Review, 9(3): 411-435.

Lesthaeghe, R., 1995. "The Second Demographic Transition in Western Countries: An Interpretation" in: Mason, K., Jensen, A. (Eds.), Gender and Family Change in Industrialized Countries. Clarendon Press, Oxford.

Lesthaeghe, R., 2007. "Second Demographic Transition" Blackwell Encyclopedia of Sociology.

Lesthaeghe, R., 2010. "The Unfolding Story of the Second Demographic Transition" Population and Development Review 36(2): 211-251.

Lesthaeghe, R., Surkyn, J., 1988. "Cultural Dynamics and Economic Theories of Fertility Change" Population and Development Review 14(1): 1-45.

Lundberg, S., Pollak, R.A., 1993. "Separate spheres bargaining and the marriage market" Journal of Political Economy 101(6): 988-1010.

McDonald, P., 2000a. "Gender Equity in Theories of Fertility Transition" Population and Development Review 26(3): 427-439.

McDonald, P., 2000b. "Gender equity, social institutions and the future of fertility" Journal of Population Research 17(1): 1-16.

Milkie, M.A., Raley, S.B., Bianchi, S.M., 2009. "Taking on the second shift: Time allocations and time pressures of US parents with preschoolers" Social Forces 88: 487-518.

Mincer, J., 1985. "Intercountry Comparisons of Labor Force Trends and of Related Developments: An Overview" Journal of Labor Economics 3(1): S1-S32. 
MTUS, 2012. Multinational Time Use Study, Versions World 5.5.3, 5.80 and 6.0 (released October 2012). Created by Jonathan Gershuny and Kimberly Fisher, with Evrim Altintas, Alyssa Borkosky, Anita Bortnik, Donna Dosman, Cara Fedick, Tyler Frederick, Anne H. Gauthier, Sally Jones, Jiweon Jun, Aaron Lai, Qianhan Lin, Tingting Lu, Fiona Lui, Leslie MacRae, Berenice Monna, José Ignacio Giménez Nadal, Monica Pauls, Cori Pawlak, Andrew Shipley, Cecilia Tinonin, Nuno Torres, Charlemaigne Victorino, and Oiching Yeung. Centre for Time Use Research, University of Oxford, United Kingdom. www.timeuse.org/mtus/

Murphy, M., 2001. "Family Theory and the Realities of Childbearing Behavior" in: Smelser, N.J., Baltes, P.B. (Eds.), International Encyclopedia of the Social \& Behavioral Sciences. Pergamon, Oxford, pp. 5361-5367.

Myrskylä, M., Goldstein, J.R., Cheng, Y.A., 2013. "New Cohort Fertility Forecasts for the Developed World: Rises, Falls, and Reversals" Population and Development Review 39(1): 31-56.

OECD, 2012. OECD Family Database, OECD, Paris. www.oecd.org/social/family/database.

Oláh, L.S., 2003. "Gendering fertility: Second births in Sweden and Hungary" Population Research and Policy Review 22(2): 171-200.

Rasul, I., 2008. "Household bargaining over fertility: Theory and evidence from Malaysia" Journal of Development Economics 86: 215-241.

Sánchez-Barricarte, J.J., Fernández-Carro, R., 2007. "Patterns in the delay and recovery of fertility in Europe" European Journal of Population 23(2): 145-170.

Schultz, T.P., 2001. "The Fertility Transition: Economic Explanations" SSRN Scholarly Paper No. ID 286291. Social Science Research Network, Rochester, NY.

Sobotka, T., 2011. "Fertility in Central and Eastern Europe after 1989: Collapse and Gradual Recovery" Historical Social Research 36(2): 246-296.

Stycos, J.M., Weller, R.H., 1967. "Female Working Roles and Fertility" Demography 4: 210217.

Sullivan, O., Billari, F.C., Altintas, E., (2014 forthcoming) "Father's changing contributions to child care and domestic work in very low fertility countries: The effect of education" Journal of Family Issues.

Testa, M.R., Skirbekk, V., Lutz, W., 2006. "The Low Fertility Trap Hypothesis. Forces that May Lead to Further Postponement and Fewer Births in Europe" Vienna Yearbook of Population Research 4: 167-192.

Torr, B.M., Short, S.E., 2004. "Second Births and the Second Shift: A Research Note on Gender Equity and Fertility" Population and Development Review, 30(1): 109-130.

Van De Kaa, D.J., 1987. "Europe’s second demographic transition" Population Bulletin 42(1): 1-59. 
Weil, D.N., 1997. Chapter 17. "The economics of population aging" in: Mark R. Rosenzweig and Oded Stark (Ed.), Handbook of Population and Family Economics. Elsevier, pp. 967-1014.

Willis, R.J., 1973. "A New Approach to the Economic Theory of Fertility Behavior" Journal of Political Economy 81(2): S14-64. 